\title{
Beroepsziekte, en toch behoud van werk
}

Willem Pieter Piebenga, Yvette Sloot

Wanneer een beroepsziekte optreedt, is terugkeer in eigen werk slechts mogelijk als de oorzaak van de aandoening wordt weggenomen. Een beoordeling van de werkplek is essentieel. Goed kijken is het halve werk, zo blijkt uit de hier beschreven casus over een autopoetser met een beroepsziekte van de huid.

\section{De casus}

Een werkgever in de autobranche vraagt in november 2019 een consult aan voor een werknemer. Het gaat om een make-upspecialist van 44 jaar, voltijds werkzaam sinds 2007, die al een tijd zijn eigen werk niet meer kan doen vanwege aanhoudende huidklachten. Het eigen werk is het afleverklaar maken van auto's. Zowel werkgever als werknemer willen graag advies van de bedrijfsarts over een plan van aanpak. Hij werkt nu in ander, aangepast werk omdat zijn eigen natte werk niet lukt vanwege de huidklachten en het droge werk lastig is vanwege de vette zalf die hij gebruikt.

Half december 2019 ziet de aios bedrijfsgeneeskunde (YS) de man. Hij maakt zich ernstige zorgen over zijn werktoekomst en ook thuis wordt hij belemmerd in de zorg van zijn kinderen door de huidklachten. Op diverse plaatsen van zijn lichaam zijn huidafwijkingen aanwezig: zijn gelaat, handen, voeten, ellebogen, knieën en scrotum zijn aangedaan. Hij heeft in het verleden nooit eerder huidklachten gehad. Voor de huidklachten is hij bij de dermatoloog geweest en die heeft 10\% salicylzuur in vaseline voorgeschreven. Voor de huidklachten aan zijn scrotum krijgt hij een corticosteroïdzalf (Betnelan $1 \mathrm{mg} / \mathrm{g}$ ).

De behandelingen bieden echter geen structurele oplossing. Hij werkt nog steeds in het aangepaste droge werk en de dermatoloog heeft geadviseerd dat hij beter structureel droog werk zou kunnen gaan doen. De aios besluit de medisch informatie op te vragen en de casus te bespreken met de praktijkopleider (WPP), die ook klinisch arbeidsgeneeskundige op gebied van beroepshuidafwijkingen is.

Drs. Willem Pieter Piebenga, bedrijfsarts en opleider bij Arbo Unie; tevens klinisch arbeidsgeneeskundige Polikliniek Mens en Arbeid, Amsterdam UMC, locatie AMC. Dr. Yvette Sloot, Arts in opleiding tot bedrijfsarts (AIOS bedrijfsgeneeskunde), Arbo Unie Correspondentie: w.p.piebenga@amsterdamumc.nl

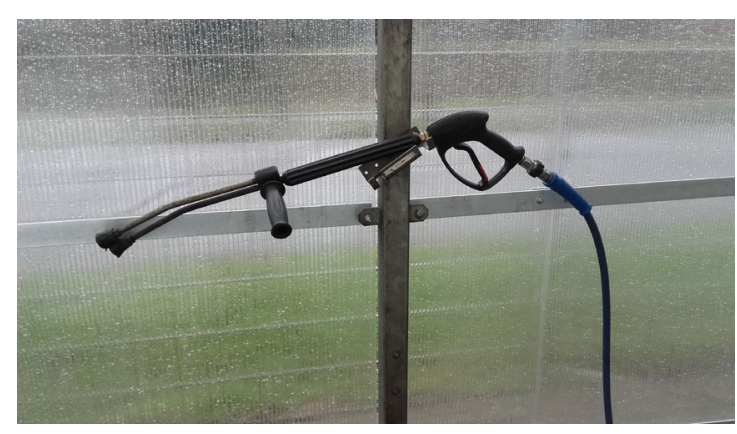

Uit de medische informatie blijkt dat na diverse differentiaaldiagnoses en behandelpogingen de huidklachten aan het scrotum geduid worden als neurodermatitis en voor de andere lokalisaties (knieën, voeten, ellebogen en gelaat) wordt de diagnose psoriasis uiteindelijk gesteld. Voor de huidafwijkingen op de handen blijft de diagnose nog onduidelijk: er is twijfel tussen de diagnoses psoriasis en ortho-ergisch handeczeem. Uit de medische informatie blijkt dat de dermatoloog inderdaad expliciet adviseert dat werknemer ander werk zou moeten krijgen. Uitkomst van overleg tussen aios en opleider is om een werkplekonderzoek te organiseren. De prognose vanuit de curatieve sector zou immers nooit meer terug in eigen werk betekenen en een tweedespoortraject. Een duur traject voor de werkgever en een lastig traject voor werknemer om weer tot een leuke baan te komen, gezien zijn scholingsachtergrond en mogelijkheden. De meerwaarde van het werkplekonderzoek zit hem in het feit dat met de informatie van de werkplek het opsporen van huidbelastende factoren), gerichtere adviezen aan zowel werknemer en werkgever gegeven kunnen worden. Er is dan een goede kans om terug te keren in het eigen werk.

\section{Het gezamenlijk werkplekonderzoek}

Het werkplekonderzoek begon opnieuw met klinisch onderzoek. We zagen een kwetsbare huid op de handen, passende bij een cumulatieve irritatieve contactdermatitis (CICD) in remissie. De medicatie was echter niet passend. Deze bevatte namelijk een exfoliant ingrediënt in een vaselinebasis. Dit is een goede medicatie voor psoriasis maar niet voor CICD. De medicatie voor zijn handen en armen is door ons vervangen door louter vettende zalf met een simpel smeerschema. 


\section{Kader 1.}

\section{NVAB richtlijn Contacteczeem (2020)}

- Cumulatieve irritatieve contactdermatitis (CICD) komt het meest voor binnen de arbeidsgerelateerde huidaandoeningen. Het ontstaat als gevolg van een cumulatie van herhaalde minimale huidbeschadigingen die elkaar langdurig en frequent opvolgen, waarbij alle huid beschadigingen de herstelcapaciteit van de huid overtreffen.

- De eerste stap is het herkennen van het huidbeeld en het onderzoeken van de huidbelastende factoren in het werk. De focus ligt hierbij op de irritatieve werkomstandigheden, maar als er concrete verdenkingen zijn op allergene expositie wordt dat ook onderzocht. Bijlage 1 en 2 van de richtlijn bieden hierbij handvatten.

- Vervolgens is het van belang om de blootstelling te kwantificeren door middel van een werkplekonderzoek. Voor het vaststellen of er sprake is van een beroepsziekte, kan verder gebruik worden gemaakt van de registratierichtlijn.

- De belangrijkste kortetermijninterventies zijn gericht op het beschermen, reinigen en invetten van de huid. Om op langere termijn een blijvend effect te bereiken worden de huidbelastende factoren zo mogelijk bij de bron aangepakt.

- Evalueer het effect van de interventies. Mocht er onvoldoende effect zijn overweeg contact allergologisch onderzoek met de stoffen van zijn werk.

- Neem ook de behandelaar of huisarts mee in dit traject, door deze op de hoogte te stellen van de bevindingen en het advies, alsook de rol die de behandelaar daarin kan hebben.

Het werk van een make-upspecialist bestaat uit het afleverklaar maken van nieuwe auto's. Daarnaast worden tweedehands auto's zoveel als mogelijk als nieuw gemaakt. Het werk bestaat uit droge werkzaamheden, werkzaamheden waarbij poetsende en schurende mid delen worden gebruikt. Incidenteel taken waarbij een ontvetter gebruikt wordt. Daarnaast bestaat een groot deel van zijn werk uit natte werkzaamheden, waarbij de auto's handmatig met een hogedrukspuit worden gereinigd. Bij bijna al deze werkzaamheden gebruikte de man geen handschoenen. Het bleek dat in de periode voorafgaand aan de huidklachten de man veel meer de hogedrukspuit heeft gebruikt. Bij een nogmaals zorgvuldige bestudering van zijn handklachten bleken de aangedane plaatsen van zijn handen volledig overeen te komen met de contactplaatsen met de hogedrukspuit. Het handvat van de hogedrukspuit en ook het lancet waren bekleed met een beschadigde rubberbekleding om de trillingen tegen te gaan. Een combi van frictie en vocht. Daarnaast mogelijk een allergene component vanuit het rubber wat zou kunnen spelen.

In de garage is een goed onderhouden handenstation aanwezig. Er worden twee zepen aangeboden: Een sterk reinigende garage zeep en een milde zeer licht reinigende zeep. Twee huidverzorgende producten zijn beschikbaar: Eén voor na het werk, de andere voor tijdens en vooraf aan het werk. De laatste was vetter dan de eerste. Er bleken bij verder onderzoek in de garage diverse handschoenen in het magazijn aanwezig te zijn, waaronder dunne pur handschoenen en dikke palmair gecoate nitrile rubber handschoenen. De middelen waren er dus wel, maar ze werden nog niet juist toegepast.

\section{Het voorgestelde beleid}

We hebben de werknemer uitgebreid uitleg gegeven wat de huidbelastende werkzaamheden zijn als make-upspecialist. Hierbij hebben we hem duidelijk kunnen maken wat de gevolgen kunnen zijn op de huid. Vervolgens hebben we hem per taak aangegeven welke handschoenen hij moet dragen en hoe hij op een juiste wijze het handstation kan gebruiken. Voor de hoge drukspuit was het advies de dikke palmair rubber gecoate handschoen te gebruiken en voor de werkzaamheden met de schurende middelen de dunne pur handschoenen. We hebben hem gevraagd het werken met de ontvetter te minimaliseren. Voor de gebruikte velgenreiniger werden nitril handschoenen geadviseerd met een lange manchet. Die konden ook bij de nog aanwezige natte klussen worden gebruikt. Belangrijk hierbij is om na het werken de handschoenen binnenste buiten te laten drogen en wekelijks te vervangen. Omdat het verder van belang is dat de huid tot rust kan komen niet bedekt wordt, is geadviseerd geen katoenen handschoenen meer te gebruiken.

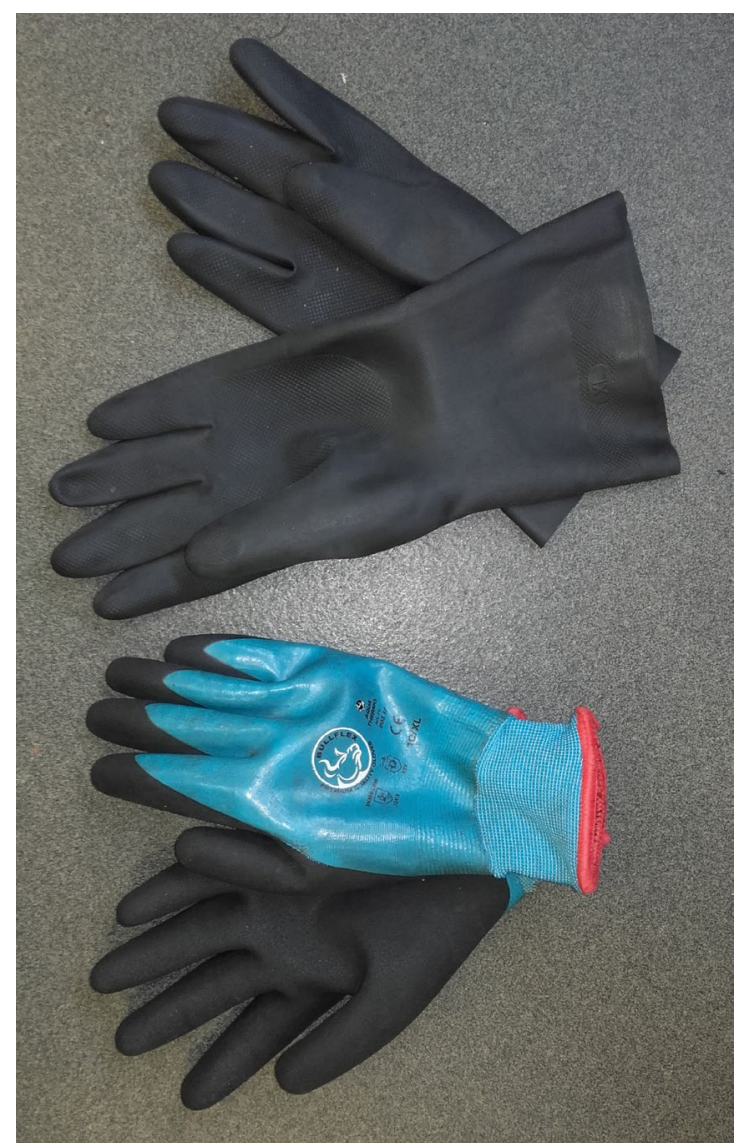




\section{Kader 2.}

NCvB registratierichtlijn Werkgebonden Contactdermatosen $(2016)^{2}$

De diagnose eczeem wordt op het klinisch beeld gesteld. Het is van belang de mogelijk oorzakelijke blootstellingen, zowel in werk als privé, goed uit te vragen. Voor de werkgerelateerde problematiek is het 6-stappenplan van de $\mathrm{NCvB}$ te volgen, waarbij de volgende vragen behulpzaam zijn

- Zijn er huidirriterende factoren c.q. werkomstandigheden (bijlage 1)? Mate en frequentie van blootstelling, intensiteit, plaats van expositie zijn belangrijk.

- Is er blootstelling aan contactallergenen (bijlage 1)?

- Stemt de expositie overeen met het eczeempatroon?

- Stemt het beloop van het eczeem overeen met het blootstellingspatroon in de tijd?

- Geeft verbreking van de blootstelling verbetering van het eczeem?

- Is afgewogen hoeveel de thuissituatie bijdraagt aan de eczeemklachten.

- Zijn interventies en maatregelen genomen gericht op het wegnemen of reduceren van de oorzaken van de beroepsziekte, vroege opsporing en/of een verbetering van de belastbaarheid van de werknemer?

$\mathrm{Bij}>3$ bevestigende antwoorden is de diagnose werkgerelateerd contacteczeem waarschijnlijk. Bij onvoldoende gegevens is een werkplekonderzoek geadviseerd.

Registreer vervolgens de beroepsziekte conform de richtlijn en gebruik hiervoor de juiste cascode. Er is hier nog wel een punt wat vermeld moet worden. Theoretisch zou er in deze casus via het Koebner fenomeen sprake kunnen zijn van een palmaire uiting van zijn psoriasis. Bij onderzoek ter plekke was het klinisch beeld veel te polymorf. Ook was er een prima reactie bij de verandering van behandeling aan de handen. Op de lokale psoriasis behandeling reageerde hij slecht maar op de louter vettende behandeling goed. Beide argumenten passen beter bij een eczeem dan bij een psoriasis. Vanuit de kliniek werd uiteindelijk ook de diagnose irritatie eczeem gesteld.

Voor het hervatten in zijn eigen werk is een opbouwschema gehanteerd betreffende de belastende werkzaamheden.

Begin maart was het volgende consult met de werknemer. Helaas waren de psoriasisklachten op de knieën, ellebogen en voeten nog niet significant afgenomen en hij zou gaan starten met lichttherapie. Het herstel van zijn huidklachten aan zijn handen en zijn scrotum verliep wel voorspoedig en hij voerde ook al zijn eigen werkzaamheden weer uit. Bij de dermatoloog werd de diagnose voor de handen nu herzien en de diagnose CICD leek nu aannemelijker, naast de diagnose psoriasis voor de andere lokalisaties en de neurodermatitis scrotaal.

In april is er nog een nazorgconsult geweest voor begeleiding. Er is hierbij veel aandacht besteed hoe hij zijn handen het beste kon verzorgen. Vanwege de COVID-19-pandemie had hij namelijk weer een toename van klachten aan zijn handen gekregen door het advies van de overheid veelvuldig de handen te wassen. Wij hebben geadviseerd de handen voornamelijk met een handalcohol met een terugvettende toevoeging te reinigen. In overleg is er nog gezocht naar een luchtigere handschoen voor het gebruik van de hogedrukspuit, vanwege de oplopende temperaturen in het voorjaar en de zomer. Er is voor de zomer een dunner variant geadviseerd. De begeleiding werd afgesloten met de afspraak dat de werknemer altijd direct de bedrijfsarts kon bellen of e-mailen bij vragen of verslechtering van zijn huidklachten.

Uit de evaluaties blijkt tot op heden dat de man zonder problemen zijn werkzaamheden kan uitvoeren. Een verder onderzoek naar mogelijke rubbercomponentallergieën (rubberen handvat hogedrukspuit) was niet meer nodig gezien dit beloop.

Hoewel zowel werkgever als werknemer initieel twijfels hadden over de meerwaarde van het werkplekonderzoek gezien de adviezen van de curatieve sector, waren beiden erg tevreden met de uitkomst, omdat betrokkene door duidelijke uitleg en adviezen zijn eigen werk kon behouden.

Deze casus bevestigt het belang van de inhoud van de recente richtlijnen ${ }^{1,2}$, zie ook kader 1 en 2 . Inventariseer de huid- belastende factoren en onderzoek hoe deze te minimaliseren. Was dat niet gebeurd in deze casus, dan was het voor deze man een tweedespoortraject geworden met veel onzekerheden voor het vinden van passende werkzaamheden.

\section{Referenties}

1. NVAB richtlijn contacteczeem 2020 https://nvab-online.nl/ richtlijnen/richtlijnen-NVAB/richtlijn-contacteczeem

2. NCvB registratierichtlijn: F002 - Werkgebonden Contactdermatosen 